\title{
Notae subsidiorum huius editionis.
}

$P=$ Ed. princ. Jo. Penae. Parisiis 1558. 4.

$H=$ Edit. Josephi Huntii. Oxon. 1707. 8.

$D=$ Sphaericae doctrinae propositiones gr. et lat. nunc primum editae per Cunr. Dasypodium. Argentorati 1572. 8.

$V=$ Theodosii de sphaericis libri tres, a Jo. Voegelino restituti etc. Viennae 1529. 4.

$M=$ Theodos. lat. p. F. Maurolycum. Messenae 1558. F. 
